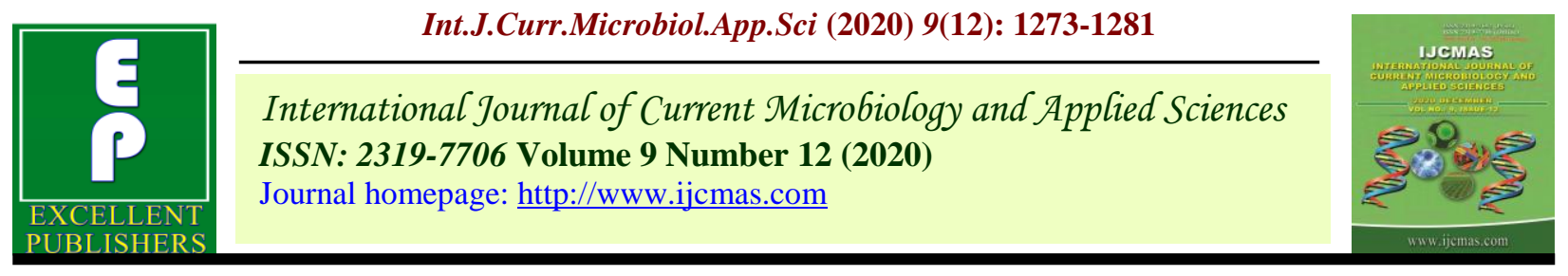

Original Research Article

https://doi.org/10.20546/ijcmas.2020.912.157

\title{
Effect of Different Levels of Yeasts and Sugars on Biochemical and Organoleptic Properties of Red Grape Wine
}

\author{
Sake Bhavani" and Samir E. Topno \\ Sam Higginbottom University of Agriculture, Technology and Sciences, Prayagraj, India \\ *Corresponding author
}

\section{A B S T R A C T}

\begin{tabular}{|l|}
\hline K e y w o r d s \\
Grape, Red wine, \\
Organoleptic, \\
Sugar, Sensory, \\
Yeast
\end{tabular}

\section{Introduction}

Fruits are natural and staple food of man. These are valued by individual of all age groups. Fruits are good sources of minerals, vitamins and enzymes. They are readily digested and have a cleansing effect on the digestive tract and blood. In India about 20 million tonnes of fruits are produced annually. But hardly $1.2 \%$ of this is utilised for processing and preservation and about 30$33 \%$ of the total production is wasted due to spoilage during handling, transportation and lack of cold storage facility (Bardiya, 1980). Due to high water or juice content, they are perishable. With increased production of
The present study was undertaken to know the effect of different levels of yeasts and sugars on biochemical and organoleptic properties of red grape wine during 20192020 at post-harvest laboratory of Department of Horticulture, Sam Higginbottom iversity of Agricultural Technology and Sciences, Prayagraj. The observations recorded based on various combinations of sugar and yeast. The findings of red grape wine. On this basis the results obtained during the present investigation sixth treatment consist of Black grape juice $(80 \%)+$ Sugar $(18 \%)+$ Wine yeast $(2 \%)$ was found as superior in terms of red grape wine on colour and appearance, flavour, taste, aroma and overall acceptability and cost effective.

particular fruit in a season, there is a glut in the market. Fruits can be effectively used in the processing industry in order to reduce post-harvest losses and to prevent market glut (Sahota and Sunil, 2006). Hence, many products like jam, jelly, squash, RTS, syrup etc., are made from fruits with preservatives which increase their shelf life substantially. Most of these products contain high level of sugar. Which are considered to be harmful to human health, if taken in excess quantity. In this aspect, the fermentation technology of fruit juices for the production of wines seems to be promising. Being a fruit-based beverage, wine provides minerals, vitamins and energy. Wine is a product of grape sugar metabolism 
through alcoholic fermentation of yeast having long shelf life. Ethanol, organic acids, glucose, fructose, glycerol, phenolic compounds, proteins, polysaccharides, volatiles and minerals such as potassium are listed among its basic constituents. Wine is a safe and healthful beverage. The alcohol in wine stimulates gastric secretions and depresses nervous system (Pradip D. Satav, 2016).

In India, grapes are mainly used for table purpose. Grapes containing $22^{\circ}$ brix are most suitable for processing (Ital et al., 1972). Grapes contain 70-80\% water,15-25\% carbohydrates and $0.2-1.0 \%$ tartaric acid, (Bose, 1985). The full ripe grape contained 17 $\%$ carbohydrates and about $0.01-0.2 \%$ protein and $\mathrm{pH} 2.9$ to 3.4 (Prahlad, 1981).

Approximately 70 percent of the overall grape production in India is harvested during the month of March and April creating a glut in the domestic market. This leads to the loss of about $25 \%$ of the produce due to its highly perishable nature and inadequate export facilities. In such condition potential benefits of grape cultivation can be stained only diverting the excess grape produced towards wine making. Grape wine is one of the most important grape products (Katyal and Gupta, 1978).

Red wine is made from red grapes which are actually similar in colour to black. There are many kind of red wines which are different. In the kingdom of wines, this is considered the most classic, incorporating the delicious red grapes with a wide variety of aromas, from oak to eucalyptus, chocolate or even mint hints. The juice of most black grapes is greenish-white; the red colour comes from the pigments of anthocyanin produced in the grape skin (Versari, 2010). Grape wine is produced from alcoholic fermentation of grape Juice. Other fruits also have been used for production of wines. Such wines are named after the fruit from which they are prepared e.g. cider (apple wine), Perry (pear wine), berry wine, cherry wine, apricot wine, pomegranate wine, ber wine, banana wine, jamun Wine etc., Being a fruit based fermented and undistilled product, wine contains most of vitamin, minerals and other nutrients present in the original fruit juice (Versari, 2010).

Decreased ovarian cancer risk (The Queensland Institute of Medical Research in Australia, 2004). Lowers of risk of stroke in women (Centre for Disease control and Prevention, 2001). It would appear therefore that enjoying wine regularly and in moderation can contribute to a long and health life (Bisson et al., 1995).

\section{Materials and Methods}

The fruits of grape variety 'Arkaneelamani' were employed in this study. These fruits are free of diseased affected, cracked and which are procured from the farmer's field of Ananthapuram district of Andhra Pradesh. All the chemicals used in the present study were of analytical grade. A pure culture of Saccharomyces cerevisiae var. Ellipsoideus (USD 552), Saccharomyces cerevisiae var. (YTPR1) Granulated sucrose (commercial sugar) was procured and stored in hygienic conditions.

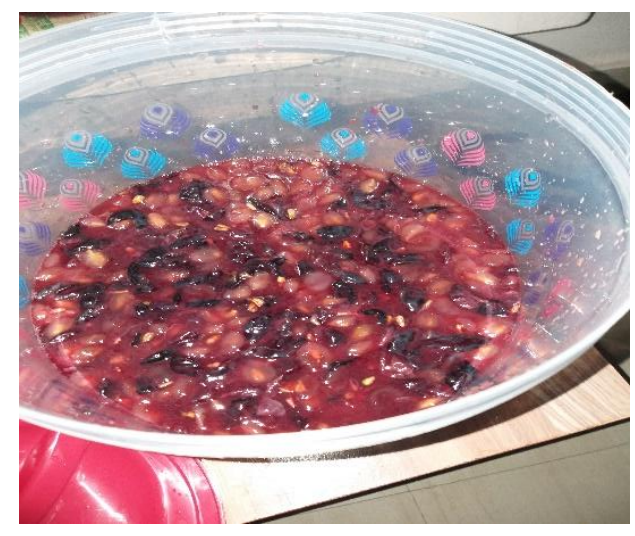




\section{Fermentation}

Healthy ripened grapes were selected after manual sorting and discarding of defective bunches. Grape berries were destemmed, then washed with boiled and cooled water and used for extraction of juice. The grapes are crushed by using wooden crusher, and extracted juice along with skin and pulp, the pulp after extraction was stored in flasks. The extracted pulp was taken into beakers $700 \mathrm{ml}$, $750 \mathrm{ml}$ and $800 \mathrm{ml}$ by using measuring cylinder as per the treatments respectively. The quantity of sugar used in the experiment was 290, 240, 190g and 280,230,180g respectively as per the treatments for both wine and baker's yeast. The sugar quantity is measured by using weighing machine.

$1 \mathrm{~g}$ and $2 \mathrm{~g}$ baker's yeast powder were added in $10 \mathrm{ml}$ of Luke warm water in separate beakers according to treatments and stirred gently. The activated baker's yeast was added to the pulp according to the treatments respectively. It has to stir daily using glass rod to remove the gas and allowed to ferment.

The measured pulp quantity of 700,750 and $800 \mathrm{ml}$ according to the treatments were transferred into the sterilized one litre beakers and added different concentrations of sugar i.e., $290 \mathrm{~g}, 240 \mathrm{~g}, 190 \mathrm{~g}$ and $280 \mathrm{~g}, 230 \mathrm{~g}, 180 \mathrm{~g}$ were added respectively. Immediately the activated wine and bakers' yeasts inoculums of $1 \%$ and $2 \%$ concentrations was added in to the beakers according to the treatments, the beakers were plugged with a cap and allowed for fermentation. Daily gas was released to decrease the pressure.

\section{Sensory analysis}

The sensory evaluation of wines of different treatments was conducted by a trained panel of 10 judges. Each judge was given a set of wines separately in isolated booths and provided with a glass of fresh water to rinse their mouth before tasting the next sample.

Each sample was evaluated for various quality attributes, viz. colour, consistency, aroma, overall acceptability, etc. as per the prescribed Performa (Amerine et al., 1980 and Joshi et al., 2006). The wine was also evaluated by judges on a scale of 20 for each attribute for analysis.

\section{Statistical analysis of data}

The quantitative estimation of various physicochemical characteristics of different wines were analysed by Completed Randomized Design as per method suggested by Panse and Sukhatne (1978), (go for new reference below 10 years please)while that of sensory evaluation was analysed by the Randomized Block Design as described by Mahony (1985).

\section{Results and Discussion}

During fermentation of fruit juices for the production of wine, utilization of sugars by the yeasts results in production of alcohol and fall in ${ }^{\circ}$ Brix of the medium. Simultaneously, other chemical changes take place, production of organic acids results in fall in $\mathrm{pH}$ and increase in acidity. The viable yeast count also increases and at a certain stage it reaches a plateau and then decreases. Levels of other constituents of medium like total phenols and anthocyanins also undergo changes. These changes may vary depending on the combination of sugar and yeast. Identification of this best combination of yeast and sugar concentration is purpose of this research

The data regarding TSS ( ${ }^{\circ}$ Brix) from the samples of red grape wine with different levels of yeast and sugar treatments combination are presented in Table (Fig. 1). 
Table.1 Analysis of variance for different observations (Mean sum of squares)

\begin{tabular}{|c|c|c|c|c|c|c|}
\hline \multicolumn{7}{|c|}{ CRD ANOVA Summary (Mean sum of squares) } \\
\hline Source of Variation & DF & TSS ( ${ }^{0}$ Brix $)$ & Acidity (\%) & Alcohol content & pH & Specific gravity \\
\hline Treatments & 11 & $16.510 * *$ & $0.679 * *$ & $4.949 * *$ & $0.132 * *$ & $0.080 * *$ \\
\hline Error & 24.000 & 0.258 & 0.044 & 0.064 & 0.010 & 0.001 \\
\hline Total & 35.000 & 5.366 & 0.243 & 1.599 & 0.048 & 0.026 \\
\hline \multicolumn{7}{|c|}{ CRD ANOVA Summary (Mean sum of squares) } \\
\hline Source of Variation & DF & $\begin{array}{c}\text { Fermentation } \\
\text { efficiency }\end{array}$ & $\begin{array}{c}\text { Color and } \\
\text { appearance }\end{array}$ & Flavour & Taste & Aroma \\
\hline Treatments & 11 & 28.364 & $1.687 * *$ & $0.816 *$ & $1.545 * *$ & $2.573 * *$ \\
\hline Error & 24.000 & 5.750 & 0.333 & 0.333 & 0.333 & 0.333 \\
\hline Total & 35.000 & 12.857 & 0.759 & 0.485 & 0.714 & 1.037 \\
\hline
\end{tabular}

Table.2 Comparison of different treatment combinations under the experiment

\begin{tabular}{|c|c|c|c|c|c|c|}
\hline Treatments & Treatment combinations & TSS $\left({ }^{0}\right.$ Brix $)$ & Acidity (\%) & Alcohol content & pH & $\begin{array}{l}\text { Specific } \\
\text { gravity }\end{array}$ \\
\hline $\mathbf{T}_{1}$ & Black grape juice $(70 \%)+$ Sugar $(29 \%)+$ Wine yeast $(1 \%)$ & 24.44 & 14.03 & 10.24 & 3.27 & 1.21 \\
\hline $\mathbf{T}_{2}$ & Black grape juice $(75 \%)+$ Sugar $(24 \%)+$ Wine yeast $(1 \%)$ & 23.37 & 15 & 11.3 & 3.43 & 1.28 \\
\hline $\mathbf{T}_{3}$ & Black grape juice $(80 \%)+$ Sugar $(19 \%)+$ Wine yeast $(1 \%)$ & 21.63 & 14.4 & 10.33 & 3.37 & 1.08 \\
\hline $\mathbf{T}_{4}$ & Black grape juice $(70 \%)+$ sugar $(28 \%)+$ Wine yeast $(2 \%)$ & 23.18 & 13.33 & 11.32 & 3.3 & 1.41 \\
\hline $\mathbf{T}_{5}$ & Black grape juice $(75 \%)+$ sugar $(23 \%)+$ Wine yeast $(2 \%)$ & 22.88 & 13.93 & 12.47 & 3.82 & 1.26 \\
\hline $\mathbf{T}_{6}$ & Black grape juice $(80 \%)+$ sugar $(18 \%)+$ Wine yeast $(2 \%)$ & 19.79 & 12.87 & 13.65 & 3.18 & 1.02 \\
\hline $\mathbf{T}_{7}$ & Black grape juice $(70 \%)+$ Sugar $(29 \%)+$ Baker's yeast $(1 \%)$ & 23.48 & 15.03 & 10.42 & 3.47 & 1.64 \\
\hline $\mathbf{T}_{8}$ & Black grape juice $(75 \%)+$ Sugar $(24 \%)+$ Baker's yeast $(1 \%)$ & 24.26 & 13.07 & 12.44 & 3.77 & 1.24 \\
\hline $\mathbf{T}_{9}$ & Black grape juice $(80 \%)+$ Sugar $(19 \%)+$ Baker's yeast $(1 \%)$ & 22.11 & 15.1 & 13.33 & 3.58 & 1.14 \\
\hline $\mathbf{T}_{10}$ & Black grape juice $(70 \%)+$ sugar $(28 \%)+$ Baker's yeast $(2 \%)$ & 22.46 & 14.03 & 11.31 & 3.54 & 1.25 \\
\hline $\mathbf{T}_{11}$ & Black grape juice $(75 \%)+$ sugar $(23 \%)+$ Baker's yeast $(2 \%)$ & 22.52 & 14.33 & 13.37 & 3.44 & 1.32 \\
\hline \multirow[t]{4}{*}{$\mathbf{T}_{12}$} & Black grape juice $(80 \%)+$ sugar $(18 \%)+$ Baker's yeast $(2 \%)$ & 20.07 & 12.87 & 13.59 & 3.22 & 1.05 \\
\hline & Mean & 22.52 & 1.43 & 11.98 & 3.45 & 1.24 \\
\hline & C.D@ 5\% & 0.356 & 0.117 & 0.189 & 0.113 & 0.062 \\
\hline & SEd $( \pm)$ & 0.172 & 0.057 & 0.091 & 0.054 & 0.03 \\
\hline
\end{tabular}


Continued...,

\begin{tabular}{|c|c|c|c|c|c|c|c|}
\hline Treatments & Treatment combinations & $\begin{array}{l}\text { Fermentation } \\
\text { efficiency }\end{array}$ & $\begin{array}{l}\text { Color and } \\
\text { appearance }\end{array}$ & Flavour & Taste & Aroma & $\begin{array}{c}\text { Overall } \\
\text { acceptability }\end{array}$ \\
\hline $\mathbf{T}_{1}$ & $\begin{array}{l}\text { Black grape juice }(70 \%)+\text { Sugar }(29 \%)+\text { Wine yeast } \\
(1 \%)\end{array}$ & 74.3 & 4 & 5.07 & 4.97 & 5.75 & 4.95 \\
\hline $\mathbf{T}_{3}$ & $\begin{array}{l}\text { Black grape juice }(80 \%)+\text { Sugar }(19 \%)+\text { Wine yeast } \\
(1 \%)\end{array}$ & 73.47 & 4.33 & 4.38 & 7.32 & 6.34 & 5.6 \\
\hline $\mathbf{T}_{4}$ & $\begin{array}{l}\text { Black grape juice }(70 \%)+\text { sugar }(28 \%)+\text { Wine yeast } \\
(2 \%)\end{array}$ & 70.67 & 5.67 & 6.89 & 7.4 & 5.23 & 6.3 \\
\hline $\mathbf{T}_{5}$ & $\begin{array}{l}\text { Black grape juice }(75 \%)+\text { sugar }(23 \%)+\text { Wine yeast } \\
(2 \%)\end{array}$ & 77.52 & 4.33 & 5.97 & 6.61 & 5.75 & 5.67 \\
\hline $\mathbf{T}_{6}$ & $\begin{array}{l}\text { Black grape juice }(80 \%)+\text { sugar }(18 \%)+\text { Wine yeast } \\
(2 \%)\end{array}$ & 79.13 & 9 & 8.85 & 9.23 & 9.16 & 9.06 \\
\hline $\mathbf{T}_{7}$ & $\begin{array}{l}\text { Black grape juice }(70 \%)+\text { Sugar }(29 \%)+\text { Baker's yeast } \\
(1 \%)\end{array}$ & 73.92 & 5 & 5.17 & 6.04 & 6.07 & 5.57 \\
\hline $\mathbf{T}_{8}$ & $\begin{array}{l}\text { Black grape juice }(75 \%)+\text { Sugar }(24 \%)+\text { Baker's yeast } \\
(1 \%)\end{array}$ & 71.22 & 2.67 & 5.3 & 4.53 & 4.94 & 4.36 \\
\hline $\mathbf{T}_{10}$ & $\begin{array}{l}\text { Black grape juice }(70 \%)+\text { sugar }(28 \%)+\text { Baker's yeast } \\
(2 \%)\end{array}$ & 75.57 & 3.67 & 5.07 & 6.07 & 5.89 & 5.17 \\
\hline $\mathbf{T}_{11}$ & $\begin{array}{l}\text { Black grape juice }(75 \%)+\text { sugar }(23 \%)+\text { Baker's yeast } \\
(2 \%)\end{array}$ & 75.42 & 5 & 6.6 & 6.5 & 5.83 & 5.98 \\
\hline \multirow[t]{4}{*}{$\mathbf{T}_{12}$} & $\begin{array}{l}\text { Black grape juice }(80 \%)+\text { sugar }(18 \%)+\text { Baker's yeast } \\
(2 \%)\end{array}$ & 77.54 & 8.67 & 8.54 & 8.49 & 7.36 & 8.26 \\
\hline & Mean & 74.45 & 5.19 & 5.97 & 6.47 & 6.2 & 5.96 \\
\hline & C.D@ 5\% & 2.439 & 2.482 & 2.416 & 1.24 & 1.022 & 0.751 \\
\hline & SEd ( $( \pm)$ & 1.176 & 1.197 & 1.165 & 0.598 & 0.493 & 0.362 \\
\hline
\end{tabular}


Table.3 Economics of different levels of yeast and sugar of red grape wine

\begin{tabular}{|c|c|c|c|c|c|c|c|c|c|c|c|}
\hline $\begin{array}{l}\text { Treatment } \\
\text { Symbols }\end{array}$ & $\begin{array}{c}\text { Black } \\
\text { Grape } \\
\text { (Rs. 100/ } \\
\text { kg) }\end{array}$ & $\begin{array}{c}\text { Sugar } \\
\text { (Rs. } \\
\text { 40/kg) }\end{array}$ & $\begin{array}{c}\text { Wine yeast } \\
\text { (Rs. } \\
\text { 100/gram) }\end{array}$ & $\begin{array}{c}\text { Baker } \\
\text { yeast } \\
\text { (Rs. } \\
\text { 240/kg) }\end{array}$ & $\begin{array}{c}\text { Bottles } \\
\text { Rs. 80/ } \\
\text { bottle }\end{array}$ & $\begin{array}{l}\text { Filter } \\
\text { Rs. } 60\end{array}$ & $\begin{array}{c}\text { Spatula } \\
\text { Rs. } 70\end{array}$ & $\begin{array}{l}\text { Mixing } \\
\text { jar Rs. } \\
\text { 50/each }\end{array}$ & $\begin{array}{l}\text { Total } \\
\text { Cost }\end{array}$ & $\begin{array}{l}\text { Selling } \\
\text { price } \\
\text { (Rs.) }\end{array}$ & $\begin{array}{c}\text { Net } \\
\text { return } \\
\text { (Rs.) }\end{array}$ \\
\hline $\mathbf{T}_{1}$ & 100.00 & 12.00 & 100.00 & 0.00 & 80.00 & 60.00 & 70.00 & 50.00 & 472.00 & 750.00 & 278.60 \\
\hline $\mathbf{T}_{2}$ & 100.00 & 10.00 & 100.00 & 0.00 & 80.00 & 60.00 & 70.00 & 50.00 & 470.00 & 750.00 & 280.00 \\
\hline $\mathbf{T}_{\mathbf{3}}$ & 100.00 & 8.00 & 100.00 & 0.00 & 80.00 & 60.00 & 70.00 & 50.00 & 468.00 & 750.00 & 282.00 \\
\hline $\mathbf{T}_{4}$ & 100.00 & 12.00 & 200.00 & 0.00 & 80.00 & 60.00 & 70.00 & 50.00 & 572.00 & 750.00 & 178.00 \\
\hline $\mathbf{T}_{5}$ & 100.00 & 10.00 & 200.00 & 0.00 & 80.00 & 60.00 & 70.00 & 50.00 & 570.00 & 750.00 & 180.00 \\
\hline $\mathbf{T}_{6}$ & 100.00 & 8.00 & 200.00 & 0.00 & 80.00 & 60.00 & 70.00 & 50.00 & 568.00 & 750.00 & 182.00 \\
\hline $\mathbf{T}_{7}$ & 100.00 & 12.00 & 0.00 & 0.24 & 80.00 & 60.00 & 70.00 & 50.00 & 372.24 & 750.00 & 377.76 \\
\hline $\mathbf{T}_{8}$ & 100.00 & 10.00 & 0.00 & 0.24 & 80.00 & 60.00 & 70.00 & 50.00 & 370.24 & 750.00 & 379.76 \\
\hline $\mathbf{T}_{9}$ & 100.00 & 8.00 & 0.00 & 0.24 & 80.00 & 60.00 & 70.00 & 50.00 & 368.24 & 750.00 & 381.76 \\
\hline $\mathbf{T}_{10}$ & 100.00 & 12.00 & 0.00 & 0.48 & 80.00 & 60.00 & 70.00 & 50.00 & 372.48 & 750.00 & 377.52 \\
\hline $\mathbf{T}_{11}$ & 100.00 & 10.00 & 0.00 & 0.48 & 80.00 & 60.00 & 70.00 & 50.00 & 370.48 & 750.00 & 379.52 \\
\hline $\mathbf{T}_{12}$ & 100.00 & 8.00 & 0.00 & 0.48 & 80.00 & 60.00 & 70.00 & 50.00 & 368.48 & 750.00 & 381.52 \\
\hline
\end{tabular}


Fig.1 Effect of different levels of yeast and sugar on TSS, Fermentation efficiency and overall acceptability

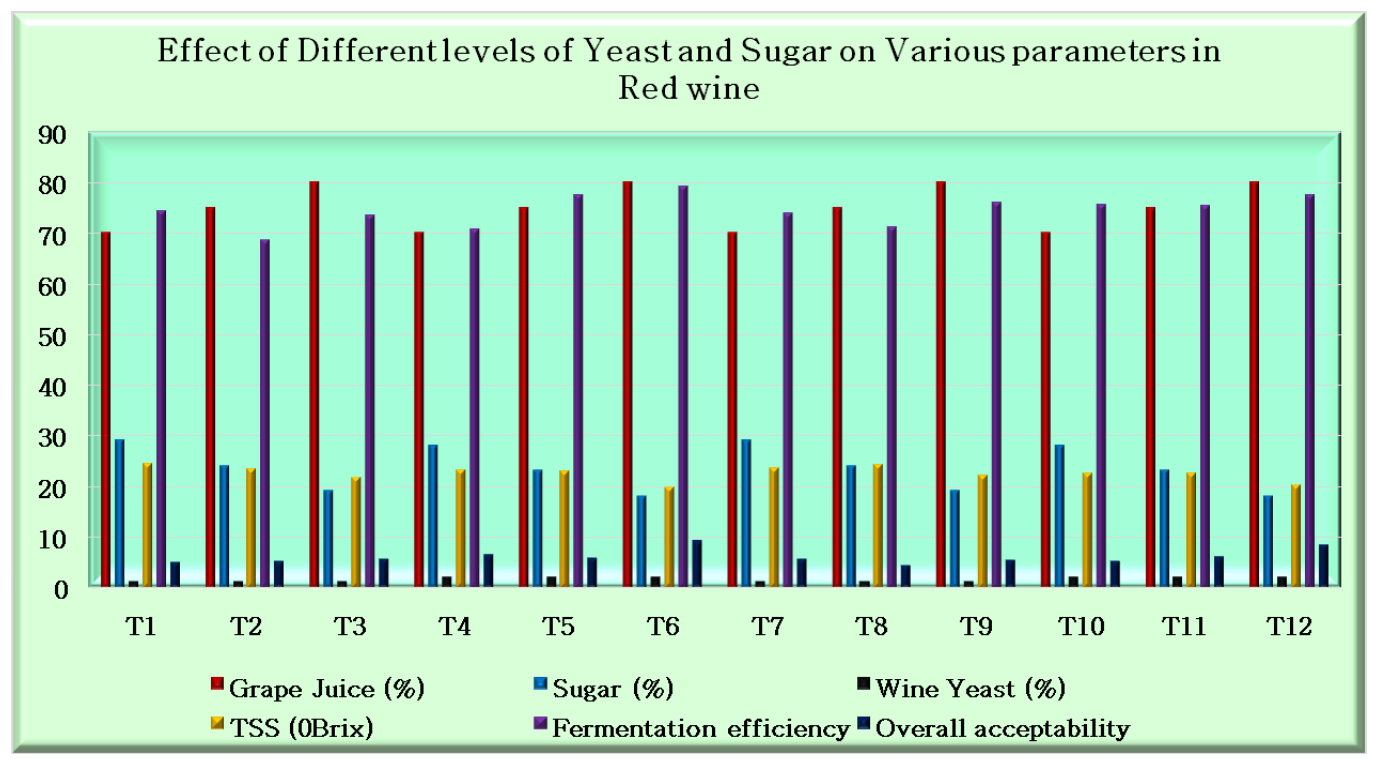

Analysis of variance presented in Table 1 there is sufficient amount of variation between treatment combinations. Therefore, the differences were significant, indicating significant effect of different levels of yeasts and sugar on TSS ( ${ }^{\circ}$ Brix) of red grape wine.

The effect of different levels of yeast and sugars on various parameters of red wine is presented in Table 2, considering the TSS value highest was obtained in case of T1 (24.44) and lowest was obtained in case of T6 (19.79). However highest acidity was shown by the T9 (15.10) while, lowest was shown by T6 (12.87). The increasing trend of acidity along with increased TSS was observed here. However, Anand (2003) reported an increase in acidity with increase in TSS levels in cashew apple wine. The range of acidity (0.52-0.77\%) obtained in present study for red wine agreed with values reported by Gautam and Chundawat (1998), Sonar (2002) for jamun wine $(0.81-1.92 \%)$ and Anand for Cashew apple wine (0.37-0.69\%). Wine acidity is responsible for its sensory characteristics and is important for its preservation. Wines with low $\mathrm{pH}$ and a high content of organic acid are less sensitive to microbial spoilage and show more stable coloration.

The alcohol content ranged in between 10.24 to 13.65 . The lowest alcohol content (10.24) was recorded in $\mathrm{T} 1$ and highest alcohol content was recorded in T6 (13.65) with minimum brix value of 19.79 .

The highest specific gravity was recorded in $\mathrm{T} 7$ and lowest was recorded in T6 while, highest $\mathrm{pH}$ was recorded in T5 while, lowest was recorded in T6. Similar results were reported by Versari et al., (2010) for red wines from grapes, with an alcohol content of 11.9\%. According to literature (Lukik et al., 2016) key matrix constituents and the relative proportion of water: ethanol in alcoholic beverages as well as their interactions with other matrix components (e.g., sugars, acids, and tannins) can also have significant effects on the behaviour of volatile compounds responsible for aroma and flavour. Alcohol content determines the formation of esters and 
other carbonyl compounds necessary in winemaking. This implies that the concentration of ethanol affects the characteristic quality and flavour of the finished product.

Clarity, colour, taste and body are the characters responsible for acceptance and rejection of any wine (Shukla et al., 1991). Red wine with different combinations of yeast and sugar kept for sensory evaluation viz. Colour, taste, appearance, aroma, astringency and overall acceptability under these sixth treatment combination performed better for overall acceptability and for cost effectiveness.

The cost of production per litre of wine observed lower (368.24) in the wine prepared by using T9 treatment combination (Table 3), while higher cost of production (572.00 Rs.) was recorded in the wine prepared by using T4 treatment combinations with net returns of 381.76rs and 178.00rs respectively. But considering overall acceptability along with cost effectiveness the T6 treatment combination was selected with the total cost of 568.00rs and net returns of 178.00rs.

In conclusion the findings obtained in this research complement those from previous work with yeast strains and sugar interaction in wine preparation. It shows that presence of oxygen, strongly affects glucose and fructose fermentation in grape must. Complexity of the nitrogen source from atmosphere, in addition to the form of cultivation (shaking) induced sugar fermentation. The treatment with lower addition of sugar and higher amount (2\%), wine yeast strain showed higher ethanol production during three months storage, however it was comparable with non-wine strains with similar sugar and yeast level. This lower level of sugar in the grape must displayed efficient sugar consumption by yeast, contrary to the higher levels of sugar
An adequate balance of sugars and yeast with nitrogen from atmosphere constituents in the fermentation process in beverage industry should be recognised as an important factor for fermentation. However, more study is needed form controlled supply of nitrogen sources with mutual interaction between carbon and nitrogen sources including yeast strains.

\section{References}

Amerine, M.A and Ough, C.S. 1980. Wine and Must analysis, 2nd Ed. 1-34. A Wiley-Inter Science Publ, John Wiley and Sons, New York.

Anand S. 2003. Evaluation of cashew apple for wine making. AThesis submitted to University of Agricultural Sciences, Dharwad,

Baisya, R. K 1980. Fruits and vegetable processing Industries in Rural India Its problem and prospects. Indian Food Packer. 34(6):29-32.

Bisson, L.F., Butzke, C.E and Ebeler, S. E. 1995. The role of moderate ethanol consumption in health and human nutrition. Amer. Jr. Enol. Vitic. 48(4): 449-460.

Gautam S. Kand Chundawat B. S. 2002. Standardization oftechnology of sapota wine making. Ind. Fd. Packer. 52(1):17-21.

Joshi V. K.2006.Sensory Science: Principles and Applications in food evaluation Agro-tech, Publish Academy, Udaipur.

Lukic', I., Radeka, S., Grozaj, N., Staver, M., Peršuric', D. Changes in physicochemical and volatile aroma compound composition of Gewürztraminer wine as a result of late and ice harvest. Food Chem. 2016, 196, 1048-1057.

Mahony, O. M., 1986. Sensory Evaluation of Food: Statistical Methods and Procedures. Marcel Dekker, New 
York.

Panse, V. G. and Sukhatme, P. V. 1978. Effect of initial sugar concentration on the physico chemical characteristics and sensory qualities of cashew apple wine. $\mathrm{Fb}$ Edition: 3rd rev. edn. Publisher: New Delhi. Indian Council of Agricultural Research.

Pradip D. Satav and Archana S. Pethe 2016. Effect of $\mathrm{pH}$ on Physicochemical Parameters of Wine Produced from Banana. Int.J.Curr.Microbiol.App.Sci., 5(2): 608-613.

Sahota PP, Sunil (2006) Preparation of nonalcoholic naturally carbonated plum beverage after optimizing the fermentation conditions. Bev and Food World 33(2): 54-58.
Shukla, K. G., Joshi, M. C., Yadav S and Bisht, N. S. 1991. Jambal wine making Standardization of a methodology and screening of cultivars. J. Food Sci. Technol. 28(3):142-144.

Priyanka Chowdhury. 2006. Preparation of wine from jamun (Syzygium cumini Linn.) juice. M.Sc. (Agri.) thesis submitted to Mahatma Phule Krishi Vidyapeeth, Rahuri, Dist. Ahmednagar (M.S.),

Versari, A. Parpinello, G. P. Scazzina, F. and Rio, D.D. 2010. Prediction of total antioxidant capacity of red wine by Fourier transform infrared spectroscopy. Food Control, 21: 786789.

\section{How to cite this article:}

Sake Bhavani and Samir E. Topno. 2020. Effect of Different Levels of Yeasts and Sugars on Biochemical \& Organoleptic Properties of Red Grape Wine. Int.J.Curr.Microbiol.App.Sci. 9(12): 1273-1281. doi: https://doi.org/10.20546/ijcmas.2020.912.157 